\title{
Mobilisation or dilution? Nitrate response of karst springs to high rainfall events
}

\author{
M. Huebsch ${ }^{1,2}$, O. Fenton ${ }^{2}$, B. Horan ${ }^{3}$, D. Hennessy ${ }^{3}$, K. G. Richards ${ }^{2}$, P. Jordan ${ }^{4}$, N. Goldscheider ${ }^{1}$, \\ C. Butscher ${ }^{1}$, and P. Blum ${ }^{1}$ \\ ${ }^{1}$ Karlsruhe Institute of Technology (KIT), Institute of Applied Geosciences (AGW), Kaiserstr. 12, \\ 76131 Karlsruhe, Germany \\ ${ }^{2}$ Teagasc, Environmental Research Centre, Johnstown Castle, Co Wexford, Ireland \\ ${ }^{3}$ Teagasc, Animal and Grassland Research and Innovation Centre, Moorepark, Fermoy, \\ Co. Cork, Ireland \\ ${ }^{4}$ University of Ulster, School of Environmental Sciences, Cromore Road, Coleraine, \\ BT52 1SA, Northern Ireland
}

Correspondence to: M. Huebsch (manuela.huebsch@partner.kit.edu)

Received: 7 March 2014 - Published in Hydrol. Earth Syst. Sci. Discuss.: 11 April 2014

Revised: 19 September 2014 - Accepted: 21 September 2014 - Published: 5 November 2014

\begin{abstract}
Nitrate $\left(\mathrm{NO}_{3}^{-}\right)$contamination of groundwater associated with agronomic activity is of major concern in many countries. Where agriculture, thin free draining soils and karst aquifers coincide, groundwater is highly vulnerable to nitrate contamination. As residence times and denitrification potential in such systems are typically low, nitrate can discharge to surface waters unabated. However, such systems also react quickest to agricultural management changes that aim to improve water quality. In response to storm events, nitrate concentrations can alter significantly, i.e. rapidly decreasing or increasing concentrations. The current study examines the response of a specific karst spring situated on a grassland farm in South Ireland to rainfall events utilising high-resolution nitrate and discharge data together with onfarm borehole groundwater fluctuation data. Specifically, the objectives of the study are to formulate a scientific hypothesis of possible scenarios relating to nitrate responses during storm events, and to verify this hypothesis using additional case studies from the literature. This elucidates the controlling key factors that lead to mobilisation and/or dilution of nitrate concentrations during storm events. These were land use, hydrological condition and karstification, which in combination can lead to differential responses of mobilised and/or diluted nitrate concentrations. Furthermore, the results indicate that nitrate response in karst is strongly dependent on nutrient source, whether mobilisation and/or di-
\end{abstract}

lution occur and on the pathway taken. This will have consequences for the delivery of nitrate to a surface water receptor. The current study improves our understanding of nitrate responses in karst systems and therefore can guide environmental modellers, policy makers and drinking water managers with respect to the regulations of the European Union (EU) Water Framework Directive (WFD). In future, more research should focus on the high-resolution monitoring of karst aquifers to capture the high variability of hydrochemical processes, which occur at time intervals of hours to days.

\section{Introduction}

The consequences of groundwater contamination by reactive nitrogen $\left(\mathrm{N}_{\mathrm{r}}\right.$, e.g. nitrate $\left.\mathrm{NO}_{3}^{-}\right)$, derived from agricultural sources, is of major concern in many countries (Galloway and Cowling, 2002; Spalding and Exner, 1993; L'hirondel, 2002). As groundwater response times affect the physical and economic viability of different mitigation measures, there is a realisation that such responses must be incorporated into environmental policy. However, such processes are poorly understood (Sophocleous, 2012), particularly where nitrate discharges unabated from high $\mathrm{N}$ input agricultural systems underlain by thin free draining soils and karst aquifers (Huebsch et al., 2013). Denitrification potential and response 
times in such systems are low (Jahangir et al., 2012a) and at karst springs processes such as mobilisation and/or dilution during rainfall events inevitably control nitrate concentrations. In the European Union (EU) the Water Framework Directive (WFD; OJEC, 2000) aims to achieve at least good water quality status in all water bodies by 2015 and for groundwater a maximum admissible concentration (MAC) of $50 \mathrm{mg} \mathrm{NO}_{3}^{-} \mathrm{L}^{-1}$ is in place. In karst regions, characterising nitrate dynamics in aquifers can help to predict when concentrations are likely to breach this MAC or not. No such standard exists for surface water but instead, in countries such as the Republic of Ireland, a much lower MAC of $11.5 \mathrm{mg} \mathrm{NO}_{3}^{-} \mathrm{L}^{-1}$ exists for estuaries (Statutory Instruments S.I. No. 272 of 2009). Recent assessments have found that $16 \%$ of Irish groundwater bodies were "at risk" of poor status due to the potential deterioration of associated estuarine and coastal water quality by nitrate from groundwater (Tedd et al., 2014). Improving our conceptual model of nitrate mobilisation and/or dilution in karst systems will therefore allow us to better manage agricultural systems in the future.

Karst areas exhibit a challenge for the protection of groundwater resources, because high heterogeneity, high vulnerability and fast groundwater flow result in low natural attenuation of contamination (Bakalowicz, 2005). Karst systems can vary significantly in the vadose zone from direct to slow infiltration and in the phreatic zone due to the complexity of conduit systems, fracture development and matrix porosity (Bakalowicz and Mangion, 2003). Episodic rainfall events can lead to rapid recharge, which has strong impact on discharge at and contaminant transport to karst springs, particularly if the conduit system is well developed (Butscher et al., 2011; Goldscheider et al., 2010). In addition, karstspecific surface features (e.g. swallow holes) can contribute to a rapid contamination of the underlying aquifer (Ryan and Meiman, 1996). As a result of all these specific characteristics, karst aquifers overlain by thin free draining soils respond quickest to changes in $\mathrm{N}$ loading on the surface (Huebsch et al., 2013).

Leaching of organic and inorganic $\mathrm{N}$ can vary significantly. Organic $\mathrm{N}$ that has been applied on the surface provides mineral $\mathrm{N}$ to the plant on a longer basis due to mineralisation processes, whereas inorganic $\mathrm{N}$ is immediately available for the plant, and hence highly susceptible to leaching, especially in the first hours to days after application (Di et al., 1998). Due to its high solubility and mobility, nitrate responds much more quickly and strongly to changes in hydrologic conditions and land use than less mobile ions such as phosphorus (Hem, 19985). Because of this, in karst aquifers, low-resolution monitoring of nitrate (e.g. on a weekly basis) is unlikely to adequately characterise the system. This is especially true during rainfall events (Pu et al., 2011). As the dynamics of the system can change not only within but also across events, it is important to have high-resolution monitoring over long time periods. Long-term high-resolution monitoring can reveal rapid dilution of nitrate concentrations
(Mahler et al., 2008), rapid mobilisation of nitrate concentrations (Baran et al., 2008; Plagnes and Bakalowicz, 2002; $\mathrm{Pu}$ et al., 2011; Yang et al., 2013) or a combination of mobilisation and dilution of nitrate concentrations during one or several rainfall events (Stueber and Criss, 2005; Rowden et al., 2001; Peterson et al., 2002).

In recent years, high-resolution monitoring in karst catchments over extended periods of time has received greater attention (Mellander et al., 2013; Schwientek et al., 2013). Also, spectrophotometrical ultraviolet/visible (UV/VIS) light monitoring, which was originally developed for monitoring waste water treatment plants (Drolc and $\mathrm{Vr}$ tovšek, 2010), has been applied to karst springs to continuously monitor nitrate concentrations (Grimmeisen et al., 2012; Pu et al., 2011). Such techniques offer the opportunity to observe both long-term trends, sudden changes of nitrate concentrations (Storey et al., 2011) and to increase the understanding of nitrate transport dynamics.

In this study, high-resolution UV monitoring, discharge and groundwater level fluctuation measurements were performed to observe nitrate concentration patterns and their relation to karst spring discharge and groundwater level fluctuations in response to storm events. The study site in southern Ireland represents an ideal test site for nitrate responses in karst springs to storm events because of the combination of intensive agronomic $\mathrm{N}$ loading on the surface, an underlying karst aquifer and hydrometeorological conditions that ensure storm events throughout the year.

By looking at different nitrate characteristics during storm events, we aim to answer the following questions: what are the key factors controlling increased (i.e. mobilised) or decreased (i.e. diluted) nitrate concentrations in karst springs as response to storm events? Does it depend on the karst system alone, the hydrological situation or land use and/or of a combination of all these components together? Specifically, the objectives of the present study are to formulate a conceptual model of possible scenarios of nitrate responses during storm events, and to verify this hypothesis using other examples from the literature together with data from our study site. The results of this study can contribute to an improved understanding of when and under what conditions nitrate is released to fresh surface waters and, therefore, can guide environmental modellers, drinking water suppliers and environmental policy makers with respect to the regulations of the EU Water Framework Directive.

\section{Materials and methods}

\subsection{Site description}

The study site of $1.1 \mathrm{~km}^{2}$ is located approximately $35 \mathrm{~km}$ north of Cork city in the Republic of Ireland and adjacent to the Teagasc, Animal and Grassland Research and Innovation Centre, Moorepark, in Fermoy $\left(8^{\circ} 15^{\prime} \mathrm{W}, 52^{\circ} 10^{\prime} \mathrm{N}\right)$. 

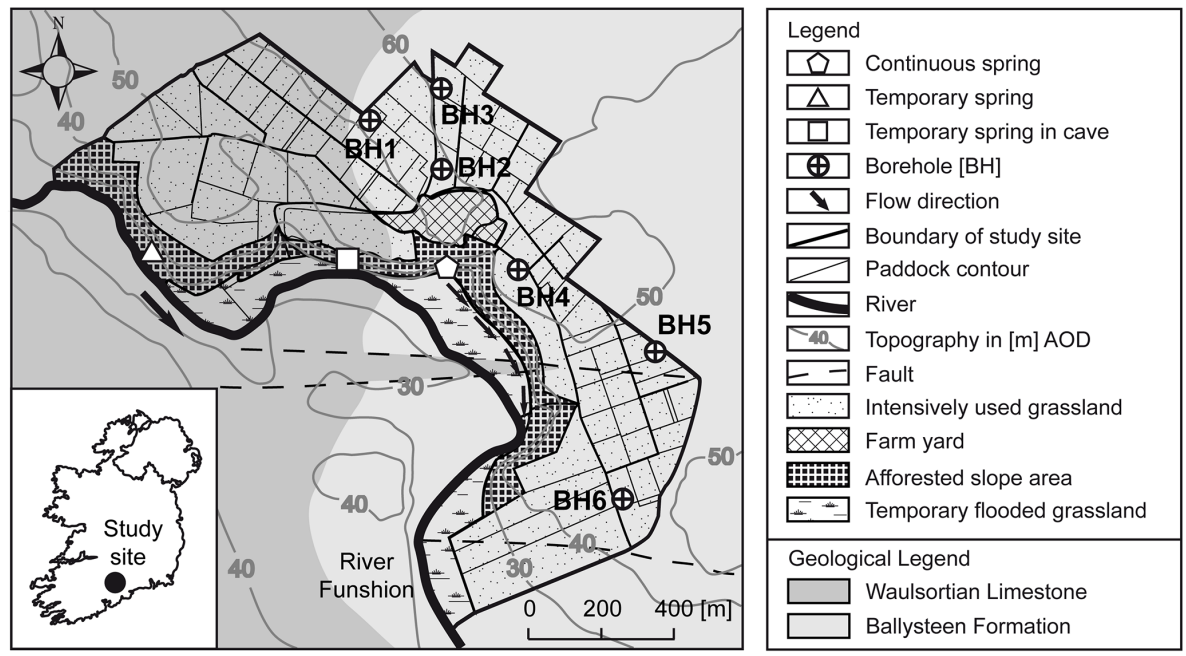

Figure 1. Site map for the study area. The smaller arrows indicate the water flow direction of the continuous spring in a ditch to the river.

About $0.97 \mathrm{~km}^{2}(\sim 90 \%)$ of the area is farmed. To the east, the study site is bounded by the River Funshion (Fig. 1). A public water supply well is located approximately $50 \mathrm{~m}$ upgradient from the most westerly part of the study site at the River Funshion. Due to the topography, the study site can be sectioned into three parts. The upper part is intensively used as grassland for dairy farming, whereas the lower part is only periodically utilised as grassland, as it can be flooded for large periods of the year due to the proximity to the River Funshion and a shallow groundwater table. A steep slope between these two parts, which is the third part of the study site, has been forested to prevent erosion. The farm yard is located centrally on the study site. It includes the housing for the dairy herd and an intensively operated piggery.

The study site has been a research farm (dairy) with a commercially farmed, intensive pig farm in the farm yard since 2006. Prior to 2006, the farm was an intensive commercial dairy and pig farm with high fertiliser and feed inputs. All nutrients (slurry, cattle and pig manures) generated on the farm were applied to the farm land. No historic nutrient records are available. Since 2006, the dairy farm has been operating as a research farm and nitrogen fertiliser application rates are maintained within the Nitrates Directive (EC, 1991) which was implemented in Ireland in 2007. Jahangir et al. (2012a) calculated the annual $\mathrm{N}$ surplus for the research farm between 2009 and 2010 at $263 \mathrm{~kg} \mathrm{~N} \mathrm{ha}^{-1}$ by subtracting the annual $\mathrm{N}$ output $\left(35 \mathrm{~kg} \mathrm{Nha}^{-1}\right)$ from input $\left(298 \mathrm{~kg} \mathrm{Nha}^{-1}\right)$. Furthermore, they estimated the possible amount of $\mathrm{N}$ leached at $148 \mathrm{~kg} \mathrm{Nha}^{-1}$ for the same years by taking $\mathrm{N}$ losses via volatilisation and denitrification in soil surface into account. All slurry and manure generated from the dairy enterprise is applied to the grassland on the farm. The piggery is privately operated and all associated nutrients (slurry and manure) are exported off the farm. The present study site is comparable with a dairy farm approx.
$2 \mathrm{~km}$ apart in terms of agronomic $\mathrm{N}$-loading, local weather conditions, hydrogeological and geological site characteristics. The neighbouring dairy farm has been described in detail by Huebsch et al. (2013). In this study agricultural practices were analysed and the applied nitrogen input on the surface was related to recorded nitrate occurrence in groundwater over an 11-year period whilst also considering a time lag from source to groundwater. The $\mathrm{N}$ inputs at this study site were 335 to $274 \mathrm{~kg} \mathrm{ha}^{-1}$ between 2001 and 2011 whereas the calculated $\mathrm{N}$ surplus ( $\mathrm{N}$ inputs $-\mathrm{N}$ exports) at farm level was 260 to $174 \mathrm{~kg} \mathrm{ha}^{-1}$. Those findings can also be compared to the study of Landig et al. (2011) who calculated N-inputs at the present study site for 2008 . $\mathrm{N}$ inputs were $337 \mathrm{~kg} \mathrm{ha}^{-1}$ while $209 \mathrm{~kg} \mathrm{ha}^{-1}$ were derived from organic $\mathrm{N}$ sources and 128 from inorganic $\mathrm{N}$ sources (Landig et al., 2009). In addition, on the present study site the availability of $\mathrm{N}$ on the land surface during autumn has increased as the farm has extended grazing during that period.

The top soil $(0-0.5 \mathrm{~m})$ of the study site consists of sandy loam, whereas the subsoil $(0.5-10.0 \mathrm{~m})$ is composed of sand and gravel (Jahangir et al., 2012b). Two different types of carboniferous limestone occur at the study site: the Waulsortian limestone and the Ballysteen Formation (Fig. 1; GSI, 2000). The Waulsortian limestone is in general less bedded and more karstified than the Ballysteen Formation due to the occurrence of massive calcareous mud-mounds and a lower content of shale components (GSI, 2000). In Fig. 1 the boundary of the two limestone types is adapted from mapping by the Geological Survey of Ireland (GSI), which was conducted at a larger scale. Therefore, and because of the lack of bedrock cores of the wells that have been drilled, the exact boundary on the local scale is uncertain.

Six boreholes (BH1 to BH6) with diameters of $150 \mathrm{~mm}$ were drilled in 2005 (Fig. 1). Five wells (BH1 and BH3 to BH6) consist of a $50 \mathrm{~mm}$ diameter piezometer casing. A 
multilevel piezometer was installed in BH1 with $6 \mathrm{~m}$ screen sections beginning at 25.18 and $43.18 \mathrm{~m}$ AOD. BH3 to BH6 each consist of a single piezometer with a $6 \mathrm{~m}$ screen section beginning at 19.85, 24.68, 20.38 and $17.57 \mathrm{~m} \mathrm{AOD}$, respectively. BH2 is an open borehole with $150 \mathrm{~mm}$ diameter. It was found to be dry to a drilling depth of $62.9 \mathrm{~m}$ and subsequently filled with water already the day after drilling. The average drilling depth on site is $45.9 \mathrm{~m}$ with a minimum depth of $31.2 \mathrm{~m}$ at $\mathrm{BH} 6$ and a maximum depth of $62.9 \mathrm{~m}$ at $\mathrm{BH} 2$.

A perennial spring is located at the foot of the slope area (Fig. 1). The spring discharge is captured in a reservoir of about $23 \mathrm{~m}^{2}$ and used as water supply for the dairy farm and the piggery. Water that is not needed for the farm flows over a weir via a channel towards the river.

\subsection{Spring, water level and meteorological data}

High-resolution monitoring of nitrate-nitrogen $\left(\mathrm{NO}_{3}-\mathrm{N}\right)$ in spring water was performed photometrically between 11 July 2011 and 20 April 2013 at 15 min intervals with a two-beam UV sensor (NITRATAX plus sc, Hach Lange GmbH, Germany) using a $5 \mathrm{~mm}$ measuring path. The sensor reports $\mathrm{NO}_{3}-\mathrm{N}$ by measuring total oxidised $\mathrm{N}$ (TON), and assuming negligible nitrite $\left(\mathrm{NO}_{2}-\mathrm{N}\right)$. To verify the UV sensor measurements, 12 water samples $(50 \mathrm{~mL})$ were taken at the sensor location in July 2011, four water samples in October 2012 and 12 water samples in May 2013. Half of the samples were filtered immediately using a $0.45 \mu \mathrm{m}$ micropore membrane, the other half were kept unfiltered to determine the influence of organic substances, as the accuracy of the sensor can be affected by those. All samples were transferred to $50 \mathrm{~mL}$ polyethylene screw top bottles, which were kept frozen prior to chemical analysis. TON and $\mathrm{NO}_{2}-\mathrm{N}$ content were determined in the laboratory (Aquakem 600A, Thermo Scientific, Finland), from which the nitrate concentration was calculated. For TON and $\mathrm{NO}_{2}-\mathrm{N}$ determination the hydrazine reduction method was used (Kamphake et al., 1967). The analysis of the unfiltered and filtered samples showed that UV sensor measurements were reliable and not affected by organic substances. $\mathrm{NO}_{2}-\mathrm{N}$ was negligible and the measured TON was reported as $\mathrm{NO}_{3}-\mathrm{N}$.

To determine spring discharge, a trapezoidal weir was installed at the outlet of the spring capture reservoir (e.g. Walkowiak, 2006). The water level in the reservoir was measured with an electronic pressure transducer (Mini-Diver, Eijelkamp, the Netherlands) in a stilling well at $15 \mathrm{~min}$ intervals. As the reservoir is used to provide water to the farm, a flow metre with data logger was also installed in the water supply pipe to measure pumped outflow. Changes in groundwater levels were continuously monitored at $15 \mathrm{~min}$ intervals in $\mathrm{BH} 1, \mathrm{BH} 3, \mathrm{BH} 4$ and $\mathrm{BH} 6$ using electronic pressure transducers (Mini-Diver, Eijelkamp, the Netherlands).

Rainfall was recorded every hour at a Met Èireann weather station of approximately $500 \mathrm{~m}$ from the study site. Effective drainage (ED) was calculated as precipitation minus actual

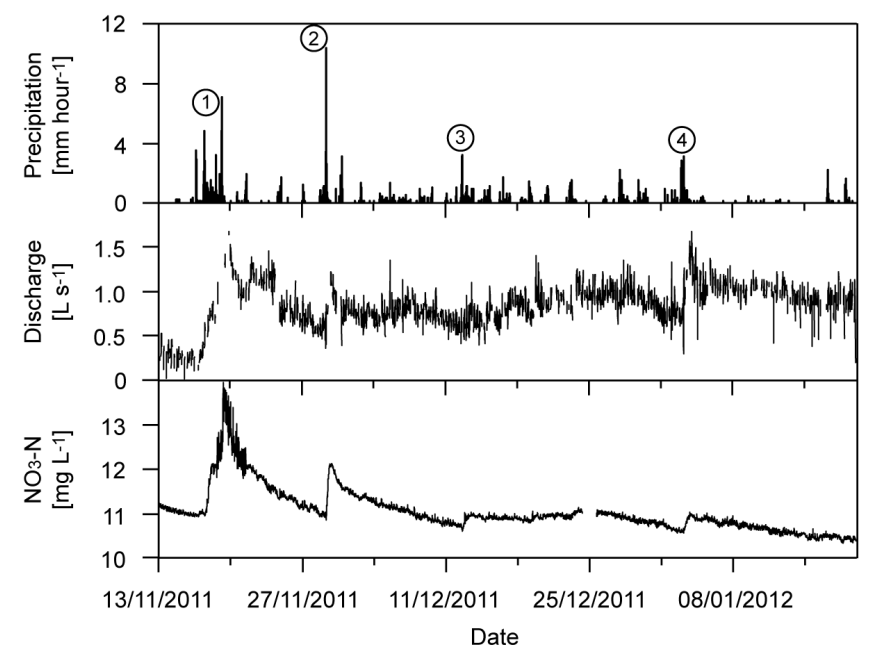

Figure 2. Observations at the study site in period (1) between 13 November 2011 and 20 January 2012. The symbols (1)-(4) indicate different storm events, which had a visible influence on the discharge and nitrate pattern at the spring.

evapotranspiration, which was calculated from daily recordings of maximum and minimum temperature, precipitation, wind speed and solar radiation at the Met Eireann weather station after Schulte et al. (2005). In 2011 the annual rainfall was $855 \mathrm{~mm}$ and ED $364 \mathrm{~mm}$, whereas in 2012 the annual rainfall was 1097 and ED $578 \mathrm{~mm}$.

\section{Results}

\subsection{Observations at the study site}

Two periods were evaluated: (1) from 13 November 2011 to 20 January 2012 including high-resolution observations of $\mathrm{NO}_{3}-\mathrm{N}$ concentrations in spring water, precipitation and discharge (Fig. 2) and (2) from 1 February to 1 October 2012 including high-resolution observations of $\mathrm{NO}_{3}-\mathrm{N}$ concentrations in spring water, precipitation and groundwater level fluctuations in $\mathrm{BH} 1, \mathrm{BH} 3, \mathrm{BH} 4$ and BH6 (Fig. 3).

Figure 2 illustrates the impact of four storm events on discharge and nitrate patterns at the spring for period (1). Storm events were separated from each other if precipitation was less than $0.2 \mathrm{~mm} \mathrm{~h}^{-1}$ for at least $24 \mathrm{~h}$ in accordance with Kurz et al. (2005). Only storm events with a total amount of minimum $10 \mathrm{~mm}$ precipitation were taken into account.

The first storm event started on 16 November 2011 at 4 p.m. and ended on 19 November at 10 a.m. A total of $60.3 \mathrm{~mm}$ precipitation was recorded during this time. Discharge started to rise on the 16th at 11.30 p.m. at $0.2 \mathrm{~L} \mathrm{~s}^{-1}$ and reached its maximum of $1.7 \mathrm{~L} \mathrm{~s}^{-1}$ on 19 November at 8.30 p.m. After the maximum was reached, discharge decreased at first, and then showed a second increase, probably due a recurrence of intensified rainfall. $\mathrm{NO}_{3}-\mathrm{N}$ concen- 


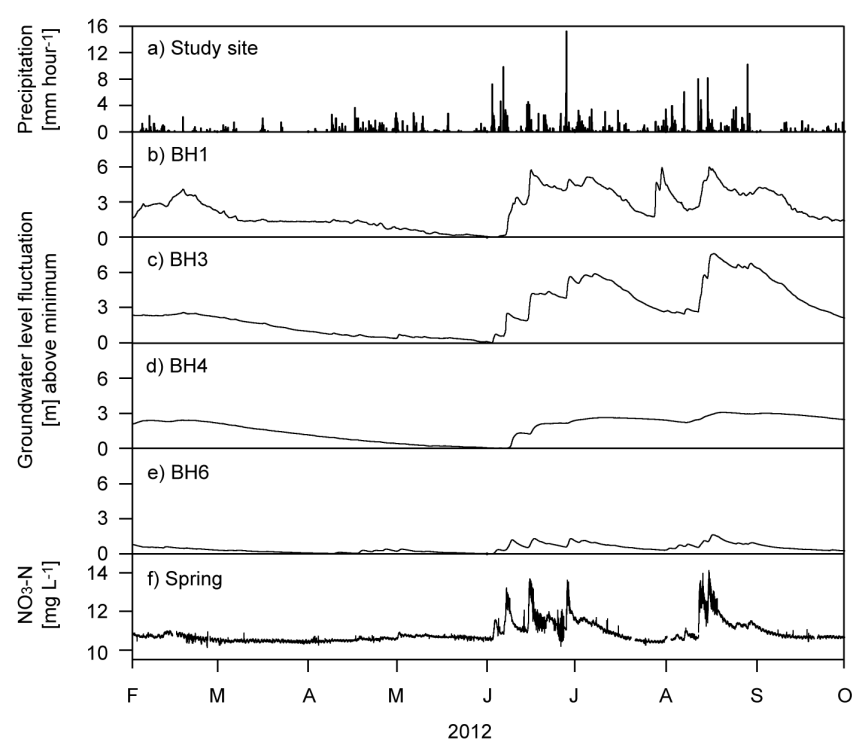

Figure 3. Observations at the study site in period (2) between 1 February and 1 October 2012: (a) precipitation; (b-e) groundwater fluctuation at BH1, BH3, BH4 and BH6 in metres above minimum; (f) $\mathrm{NO}_{3}-\mathrm{N}$ pattern at the spring.

trations increased around $18.5 \mathrm{~h}$ later than discharge on 17 November at 5 p.m. and rose to $13.8 \mathrm{mg} \mathrm{L}^{-1}$ until 19 November at 10.45 a.m. Hence, the $\mathrm{NO}_{3}-\mathrm{N}$ increase started later than the discharge increase but reached its maximum $9.75 \mathrm{~h}$ earlier. After the maximum was reached, $\mathrm{NO}_{3}-\mathrm{N}$ exponentially decreased to $11.0 \mathrm{mg} \mathrm{L}^{-1}$ until 29 November at 9 a.m.

The second storm event started on 28 November 2011 at 5 p.m. Rainfall intensified and reached a total of $33.5 \mathrm{~mm}$ by 30 November at 10 p.m. Discharge started to increase at $0.5 \mathrm{~L} \mathrm{~s}^{-1}$ on 28 November at 10.45 p.m., and the first maximum discharge of $1.2 \mathrm{~L} \mathrm{~s}^{-1}$ was measured on 29 November at 7.30 p.m. However, the maximum discharge could have been higher and earlier. Intensive pumping at the reservoir between 12.15 and 7 p.m. led to a lack of stationary discharge values during that time. The increased discharge value of $1.0 \mathrm{~L} \mathrm{~s}^{-1}$ or more was maintained until 30 November 2.30 a.m. and decreased afterwards. The $\mathrm{NO}_{3}-\mathrm{N}$ concentrations started to increase at 29 November at 9 a.m. at $11.0 \mathrm{mg} \mathrm{L}^{-1}$ and reached a maximum of $12.1 \mathrm{mg} \mathrm{L}^{-1}$ on 29 November at $5.45 \mathrm{p} . \mathrm{m}$. The $\mathrm{NO}_{3}-\mathrm{N}$ peak was observed about $1.45 \mathrm{~h}$ earlier than the discharge peak.

During the third and fourth storm event, the same characteristics as described in the aforementioned storm events were observed at the spring. The total amount of precipitation was $28.8 \mathrm{~mm}$ for the third event and $18.7 \mathrm{~mm}$ for the fourth event. After rainfall intensified, discharge rose followed by increased $\mathrm{NO}_{3}-\mathrm{N}$ concentrations a few hours later. Again, the maximum $\mathrm{NO}_{3}-\mathrm{N}$ concentrations were reached earlier than the discharge peak. Specifically, during the third storm event discharge started to rise at $0.4 \mathrm{~L} \mathrm{~s}^{-1}$ on 12 December 2011 at
11.45 a.m., while $\mathrm{NO}_{3}-\mathrm{N}$ started to increase at $10.6 \mathrm{mg} \mathrm{L}^{-1}$ on 12 December 2011 at 3.15 p.m. Highest discharge values were observed at $1.1 \mathrm{~L} \mathrm{~s}^{-1}$ on 13 of December 2011 at 12.30 p.m. The $\mathrm{NO}_{3}-\mathrm{N}$ peak was reached at $11.0 \mathrm{mg} \mathrm{L}^{-1}$ at $11.15 \mathrm{a} . \mathrm{m}$. on the same day and was therefore $1.15 \mathrm{~h}$ earlier than the discharge peak. During the fourth storm event discharge started to increase at $0.3 \mathrm{~L} \mathrm{~s}^{-1}$ on 3 January 2012 at 4.30 a.m. and $\mathrm{NO}_{3}-\mathrm{N}$ started to rise at $10.6 \mathrm{mg} \mathrm{L}^{-1}$ on the same day at $5.00 \mathrm{a} . \mathrm{m}$. The maximum discharge was reached at $1.5 \mathrm{~L} \mathrm{~s}^{-1}$ on 4 January 2012 at $0.15 \mathrm{a} . \mathrm{m}$. and the maximum $\mathrm{NO}_{3}-\mathrm{N}$ concentration at $11.0 \mathrm{mg} \mathrm{L}^{-1}$ on 3 January 2012 at 7 p.m. Thus, the discharge maximum was reached $5.25 \mathrm{~h}$ later than the $\mathrm{NO}_{3}-\mathrm{N}$ maximum.

In addition, groundwater level fluctuations at $\mathrm{BH} 1$ and $\mathrm{BH} 3$ to BH6 were observed and can be related to precipitation and $\mathrm{NO}_{3}-\mathrm{N}$ concentrations at the spring (Fig. 3). During 1 February 2012 and 1 October 2012 groundwater level fluctuations in the boreholes accounted for up to $7.60 \mathrm{~m}$. BH1 and BH3 had maximum water level fluctuations of $5.98 \mathrm{~m}$ on 15 August 2012 and 7.60 m on 17 August 2012, respectively. In the eastern part of the study site (Fig. 1), maximum water level fluctuations were lower. At BH4 and BH6 maximum values of $3.06 \mathrm{~m}$ on 20 August 2012 and $1.62 \mathrm{~m}$ on $17 \mathrm{Au}$ gust 2012, respectively, were observed. In all wells, the lowest groundwater level was observed at the beginning of June 2012 after a longer period of sparse precipitation. BH1 and $\mathrm{BH} 3$ in particular showed similar groundwater level fluctuation patterns as the response of $\mathrm{NO}_{3}-\mathrm{N}$ concentrations at the spring. Groundwater level fluctuations are reflecting ED. Between 11 February 2012 and 25 April 2012 no ED occurred. Little ED was observed between 26 April 2012 and 10 June 2012 with a maximum peak of 13.3 and $27.3 \mathrm{~mm}$ in total. Between 11 June 2012 and 2 July 2012 no ED occurred. During those periods groundwater levels dropped and no significant change in nitrate concentrations was observed at the spring. In the following period ED increased and three higher ED events $>20 \mathrm{~mm}$ were observed on 7 June $2012(23.7 \mathrm{~mm})$, 15 June 2012 (21.4 mm) and 28 June 2012 (27.4 mm). In August 2012 on the 12th and on the 15th high ED $>20 \mathrm{~mm}$ of 25.4 and $25.1 \mathrm{~mm}$, respectively, was observed. In Fig. 3 the high amounts of ED match with significantly increased nitrate concentrations at the spring. The maximum nitrate concentrations during the five events were $13.2 \mathrm{mg} \mathrm{L}^{-1}$ on 7 June 2012 at 5.30 p.m., $13.7 \mathrm{mg} \mathrm{L}^{-1}$ on 15 June 2012 at 6.30 p.m., $13.6 \mathrm{mg} \mathrm{L}^{-1}$ on 28 June 2012 at 9.00 a.m., $13.6 \mathrm{mg} \mathrm{L}^{-1}$ on 12 August 2012 at 7 p.m. and $14.1 \mathrm{mg} \mathrm{L}^{-1}$ on 15 August 2012 at 6 p.m.

\subsection{Conceptual model of nitrate responses in karst systems}

A conceptual model of nitrate responses in karst groundwater systems was developed to elucidate the relationship between nitrate responses in karst springs and proposed driving fac- 


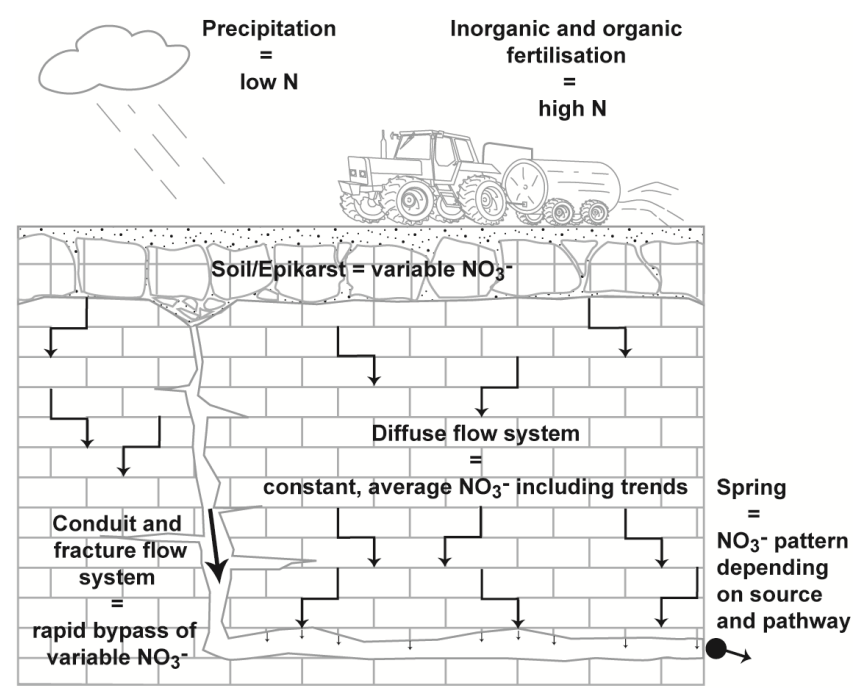

Figure 4. Conceptual model of nitrate response in karst systems.

tors such as hydrological conditions, $\mathrm{N}$ availability through land use and karst features (Fig. 4).

Agriculture is known to be a main contributor of nitrate in groundwater, mainly because of inorganic and organic $\mathrm{N}$ fertilisation (Stigter et al., 2011). Current and past $\mathrm{N}$ applications, storage capacity and hydrological conditions can result in nitrate accumulation in the soil and epikarst (Fig. 4), while rainwater itself is typically low in nitrate concentration (about $0.3 \mathrm{mg} \mathrm{L}^{-1}$; Gächter et al., 2004).

Groundwater flow in karst aquifer aquifers can be conceptualised by a dual-flow system: water flows in pipe-like conduits and open cave stream channels (conduit flow system) as well as through fractures and pores (diffuse flow system). This dual-flow concept is described in the literature and widely used in karst studies (e.g. Shuster and White, 1971; Atkinson, 1977; White, 1988; Kiraly, 1998; Ford and Williams, 2007). Other researchers use a triple porosity concept for the description of karst aquifers, where groundwater flow is attributed to conduits, pores of the rock matrix and an intermediate flow system representing fissures and joints (e.g. Worthington et al., 2000; Baedke and Krothe, 2001). In the conceptual model of the present study, the simpler dual-porosity concept is used, which is well suited to describe the nitrate characteristics of the observed karst springs. Nitrate that recharges into the diffuse flow system during a storm event can hardly change nitrate concentrations within this large groundwater storage (Peterson et al., 2002). Hence, groundwater in the diffuse flow system is characterised by relatively stable nitrate concentrations that reflect average nitrate values of groundwater recharge and long-term trends. At the spring, stable nitrate concentrations representing water from the diffuse flow systems can be observed during base flow conditions.

During a storm event, water recharges also into the conduit flow system and bypasses the diffuse flow system. Ni-
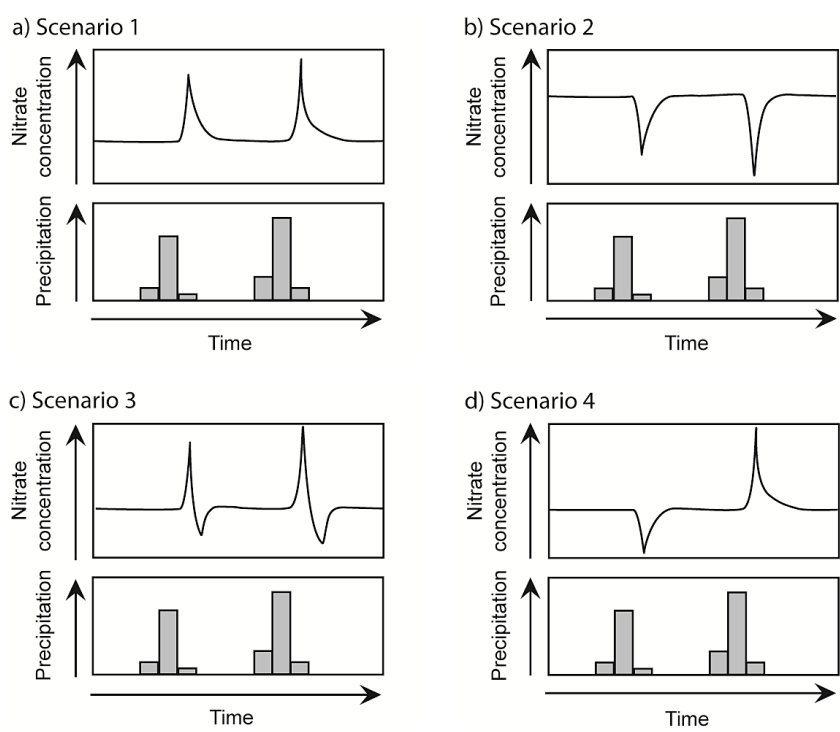

Figure 5. Hypothesis of nitrate response scenarios: predominance of (a) mobilised nitrate; (b) diluted nitrate; (c) mobilisation and dilution during one event; (d) mobilisation and dilution during multiple rainfall events.

trate concentrations of this recharge water strongly depend on hydrological conditions and land use. If nitrate concentrations in the soil and epikarst are high prior to a storm event, for example after $\mathrm{N}$ fertilisation, nitrate becomes mobilised and water with high nitrate concentration enters the conduit flow system. At the spring, a fast increase of nitrate concentrations can be observed as a storm response, which reflects nitrate mobilisation in the soil and epikarst by storm water. If nitrate concentrations in the soil and epikarst are low prior to a storm event, rainwater with low nitrate concentration enters the conduit flow system without a marked increase in nitrate concentration. At the spring, a fast decrease of nitrate concentrations can be observed as a storm response, which reflects the dilution of spring water by storm water.

Our conceptual model of karst spring responses to storm events can be summarised in four possible scenarios (Fig. 5). Scenario 1 (Fig. 5a) shows mobilisation of nitrate in the soil/epikarst during storm events and fast increasing nitrate concentrations as response at the spring, corresponding to observations of period (1) and (2) in the present study. Scenario 2 (Fig. 5b) shows dilution of spring water after storm events with fast decreasing nitrate concentrations. In Scenario 3 (Fig. $5 \mathrm{c}$ ), nitrate in the soil/epikarst becomes mobilised during storm events, resulting in an initial increase in nitrate concentrations in spring water, followed by dilution of spring water with low nitrate storm water when groundwater recharge continues after mobilised nitrate has been flushed through the system. Scenario 4 (Fig. 5d) shows different responses to storm events depending on the availability of nitrate in the soil/epikarst. During the first event, little nitrate was available and dilution can be observed at the spring. 
Before the second event, high nitrate concentrations accumulated in the soil/epikarst. Nitrate then becomes mobilised during the second storm event and a sharp nitrate peak can be observed as response at the spring.

The fast increase in nitrate concentrations after storm events indicates that mobilisation is the main process influencing nitrate patterns at the spring (Figs. 2 and 3). At the site, intensive agriculture is the dominant land use including application of inorganic and organic $\mathrm{N}$ fertiliser. During dry weather, soil moisture deficit leads to an accumulation of nitrate and minor to zero leaching in the soil. This can be recognised at the spring during base flow conditions when nitrate concentrations remain fairly constant (for example between March and May 2012, Fig. 3). During storm events (for example in June 2012), residual nitrate that was not consumed by plants gets mobilised in the soil (Fig. 5a). At the spring, the rapid increase of nitrate concentrations, only a few hours after the start of a storm event, indicates that recharging water rapidly bypasses the diffuse flow systems in the rock matrix in activated conduit systems.

\subsection{Comparison with other studies}

To further test our conceptual model, documented nitrate responses to storm events were reanalysed with respect to the proposed processes (Fig. 4) and related to the various possible scenarios (Fig. 5). Four representative studies were selected that correspond to Scenarios 1-4 (Fig. 6).

\section{Study 1 - Yverdon karst aquifer system, Switzerland (Pronk et al., 2009)}

In this study, a similar response of discharge and nitrate concentrations after a storm event as in the present study was observed (Fig. 6a). During the whole study period, a nitrate range of 1.0 to $7.0 \mathrm{mg} \mathrm{NO}_{3}-\mathrm{NL}^{-1}$ and a discharge range of 21 to $539 \mathrm{~L} \mathrm{~s}^{-1}$ was monitored. After the storm event, discharge increased at the spring, followed by a steep nitrate increase with a slower drop down after the maximum was reached. According to our conceptual model, this pattern corresponds to mobilisation (Scenario 1, Fig. 5a). Pronk et al. (2007) observed that a stream draining into a swallow hole in an agriculture-dominated area contributes significantly to nitrate variations at the spring during storm events. Their interpretation is in line with the conceptual model of the present study, where mobilisation in the soil/epikarst and subsequent transport of nitrate via the conduit flow system occur, i.e. rapidly by-passing the diffuse flow system of the rock matrix.

\section{Study 2 - Chalk aquifer in Normandy, France, and Edwards aquifer, Texas, USA (Mahler et al., 2008)}

In the second study, the observed predominant process after storm events (Fig. 6b) corresponds to dilution according to our conceptual model (Scenario 2, Fig. 5b). The observed
$\mathrm{NO}_{3}-\mathrm{N}$ concentrations in the aquifer range between 2.2 and $9.0 \mathrm{mg} \mathrm{L}^{-1}$. Three days after the storm event, nitrate concentration decreased rapidly and rose gradually afterwards. The authors state that (recharging) surface runoff was rapidly transported through the conduit system, leading to dilution effects during the storm event. When the event water became increasingly replaced after the event by groundwater stored in the rock matrix, nitrate concentrations started to rise again.

\section{Study 3 - Big Spring basin, Iowa, USA (Rowden et al., 2001)}

In the third study, a storm event of $20 \mathrm{~mm}$ in total caused first predominance of mobilisation, directly followed by dilution during one event (Fig. 6c). This nitrate pattern corresponds well to Scenario 3 in our conceptual model (Fig. 5c). Rising nitrate concentrations during the event can be explained by first mobilisation of nitrate by infiltrating recharge, followed by dilution after mobilised nitrate is already flushed through the system and storm water continues to recharge into the conduit flow system. During the study period, discharge ranged from 300 to $7300 \mathrm{~L} \mathrm{~s}^{-1}$ and $\mathrm{NO}_{3}-\mathrm{N}$ from 1.3 to $6.0 \mathrm{mg} \mathrm{L}^{-1}$.

\section{Study 4 - Karst watershed, Illinois, USA (Stueber and Criss, 2005)}

In this study, predominance of mobilisation during one and dilution during other events were observed (Fig. 6d), corresponding to Scenario 4 (Fig. 5d) of our conceptual model. Between May 2000 and December 2002, the authors frequently observed dilution during storm events. However, during one storm event, nitrate concentrations showed a different response - the concentrations increased rapidly (Fig. 6d, grey bar). The cause of the sharp nitrate increase was detected as heavy $\mathrm{N}$ fertilisation in the catchment during this time. A relatively constant $\mathrm{NO}_{3}-\mathrm{N}$ trend was monitored at $3.5 \mathrm{mg} \mathrm{L}^{-1}$, whereas during storm events concentrations decreased to $0.2 \mathrm{mg} \mathrm{L}^{-1}$ and increased up to $5.6 \mathrm{mg} \mathrm{L}^{-1}$.

\section{Discussion}

In this section, the role of different key drivers in resulting nitrate responses at karst springs is discussed, including the hydrogeological setting of the karst system, mixing of water from different sources, hydrological conditions and land use practices. In addition, adequate sampling strategies for studying nitrate characteristics of karst systems are briefly discussed.

Transport of nitrate can occur quickly within conduits and fissures or be strongly retarded in less mobile water within the rock matrix (Baran et al., 2008). Hence, the development of the karst system itself plays an important role. But what karst features are most relevant for dilution and mobilisation processes? 
a) Scenario 1

after Pronk et al. (2009)

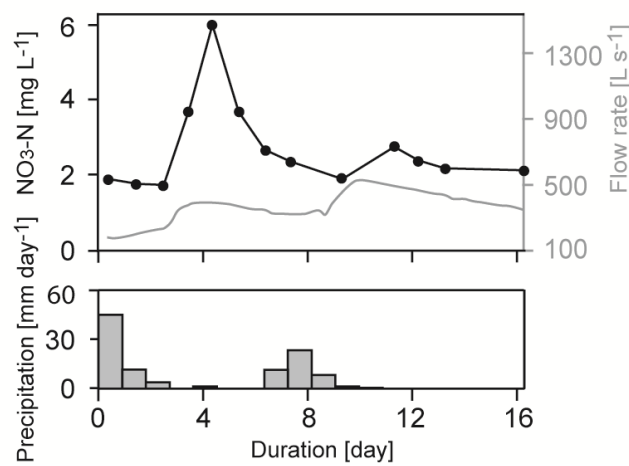

c) Scenario 3

after Rowden et al. (2001)

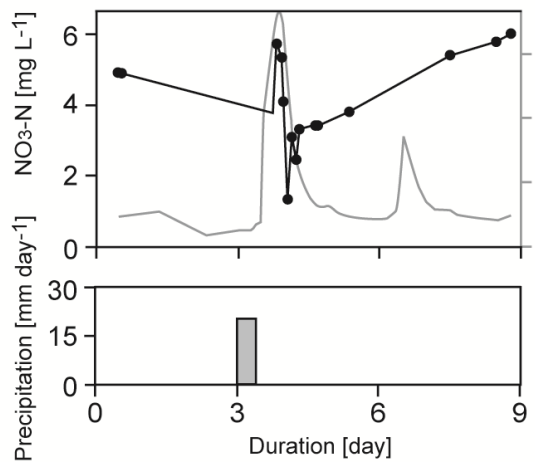

b) Scenario 2

after Mahler et al. (2008)

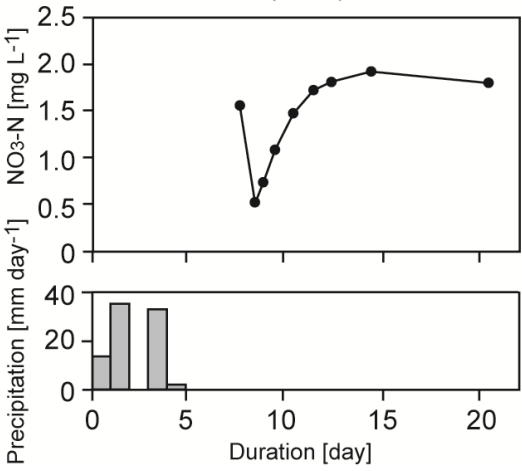

d) Scenario 4

after Stueber and Criss (2005)

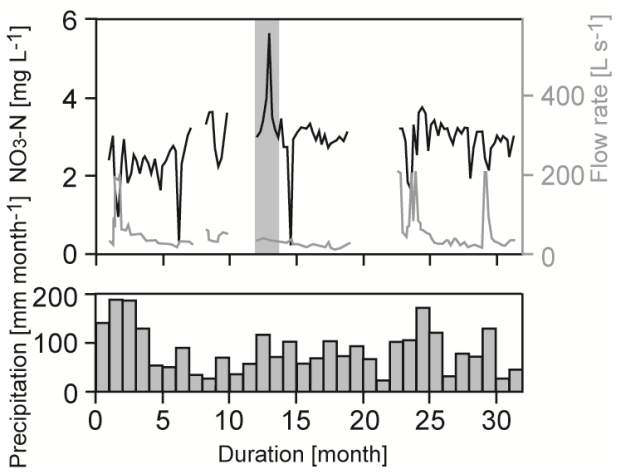

Figure 6. Illustrating 4 case studies: Predominance of (a) mobilised nitrate; (b) diluted nitrate; (c) mobilisation and dilution during one single event; (d) mobilisation and dilution during multiple rainfall events. The grey bar in the upper diagram shows the only event in the data set where mobilisation occurred instead of dilution during storm events.

In the study of Pronk et al. (2009), a sinking stream strongly impacts nitrate concentrations (and faecal bacteria) in spring water after storm events. The sinking stream points at the presence of a well-developed conduit system in the karst aquifer. The spring investigated in their study shows the same nitrate characteristics as the spring investigated in the present study. Also at the present study site, the existence of a well-developed conduit network is likely. For example, a cave exists at the study site (Fig. 1). However, the exact hydraulic properties of the karst system are uncertain.

In the study by Mahler et al. (2008) two karst systems that differ significantly in matrix porosity, thickness of soil and epikarst and land use were compared. In both karst systems, dilution was the observed predominant process after storm events. One karst system of this study is illustrated as an example in Fig. 6b. In contrast, the study of Baran et al. (2008), which focuses on a chalk aquifer in northern France comparable to one of the karst systems described in the aforementioned study of Mahler et al. (2008), shows predominance of nitrate mobilisation and not dilution, just as in the present study. Both chalk aquifers are characterised by a total matrix porosity of 30 to $40 \%$, low hydraulic conductivity of about $10^{-9}$ to $10^{-8} \mathrm{~m} \mathrm{~s}^{-1}$ and the presence of a conduit system with an observed hydraulic conductivity of $10^{-3} \mathrm{~m} \mathrm{~s}^{-1}$ (Mahler et al., 2008) and $10^{-5}$ to $10^{-3} \mathrm{~m} \mathrm{~s}^{-1}$ (Baran et al., 2008). Nevertheless, a dual-flow system will react differently to an isolated conduit system. A lower magnitude of the varying concentration is expected and the time lag between rise in spring discharge and response in concentration should be higher (Birk et al., 2006).

Similarly, Rowden et al. (2001) observed that the combination of infiltration and runoff recharge can have a significant influence on nitrate patterns at springs. The proportion of runoff recharge can vary significantly and changed in the study by Ribolzi et al. (2000) between $12 \%$ for low-intensity rain fall events and $82 \%$ for high-intensity rainfall events. In the study by Peterson et al. (2002) a step multiple regression analysis technique was used. The authors state that base flow conditions had an influence of $74 \%$ of the nitrate concentrations at the karst spring and storm events made up to $26 \%$. Even if higher nitrate concentrations in soil cores can be directly related to fertilisation, during storm events surface runoff is dominating in well-developed karst systems. Thus, recharging water contains mainly surface-derived nitrate and 
the impact of soil nitrate is only minor (Peterson et al., 2002). Zhijun et al. (2010) related a higher increase in nitrate concentrations in groundwater to rapid transportation after storm events combined with previous intensive $\mathrm{N}$ fertilisation in the catchment.

Ribolzi et al. (2000) monitored nitrate concentrations in a spring in a Mediterranean catchment and observed the predominance of either dilution or mobilisation during different rainfall events. Their results are similar to the results of the study by Stueber and Criss (2005) which were reanalysed in this study (Fig. 6d). They observed that mobilisation of nitrate concentrations occurred only after heavy $\mathrm{N}$ fertilisation coinciding with increased rainfall intensity of $107 \mathrm{~mm}$ during a four-week period. From this it follows that the different nitrate behaviour at the spring depends on source combination of land use and hydrological conditions. Similarly, Ribolzi et al. (2000) stated that dilution during one event was the result of mixing of rainwater containing low nitrate concentrations and groundwater, whereas mobilisation during another event occurred due to mixing of two different groundwater types while water levels increased. This is similar to the interpretations of Toran and White (2005), who suggest that nitrate changes can depend on changing recharge pathways in karst environments.

Denitrification potential can vary in space and time in karst aquifers (Heffernan et al., 2012). Musgrove et al. (2014), for example, studied two hydrogeologically differing karst aquifers regarding their denitrification potential: the oxic Edward aquifer and the anoxic Upper Floridan aquifer in Florida (US). They concluded that, despite the differences in hydrogeology and in oxic/anoxic conditions, nitrate concentrations of spring water were strongly influenced by fast conduit-driven flow. These observations are in line with the conceptual model of the present study, where nitrate responses to storm events at karst springs are mainly influenced by rapid flow in the conduit system, and denitrification in the diffuse flow system (rock matrix) may influence nitrate characteristics of the spring (only) during base flow conditions significantly. Also Panno et al. (2001) observed a significant degree of denitrification in karst springs on the western margin of the Illinois Basin (Illinois, US). These authors reported a high density of sinkholes which caused rapid influx of agrichemicals to the springs, accounting for highest nitrate concentrations (Panno, 1996). These observations also justify the conceptual model of the present study, which is based on the assumption that the diffuse flow system transfers average nitrate concentrations and may account for longterm trends, while rapid bypass of lower or higher nitrate concentrations after storm events via karst conduits accounts for (mobilised or diluted) peak concentrations at the spring. Nevertheless, water that flows through the karst matrix with longer travel time is likely to be affected by denitrification and redox processes (Einsiedl et al., 2005; Liao et al., 2012; White, 2002). One should therefore bear in mind that such processes can also contribute to variable nitrate concentrations at karst springs.

In the conceptual model (Fig. 4), precipitation is conceptualised as a low-N source. However, precipitation can also be enriched with atmospheric-derived nitrate (Einsiedl and Mayer, 2006). Sebestyen et al. (2008) showed for a catchment in an upland forest in Northeast Vermont, USA, that atmospheric-derived nitrate can account for more than $50 \%$ of nitrate concentrations in groundwater, especially during snowmelt. In the same catchment, Campbell et al. (2004) estimated the average total $\mathrm{N}$ input from atmospheric derived nitrate to be $13.2 \mathrm{~kg} \mathrm{ha}^{-1} \mathrm{a}^{-1}$, which can be significant in such a catchment where atmospheric nitrogen is the most influencing nitrate source. However, this $\mathrm{N}$ input is relatively low compared to an intensively operated agricultural area. In Ireland, for example, the Nitrates Directive (EC, 1991) allows cattle stocking rates with a nitrate input of 170 or $250 \mathrm{~kg} \mathrm{ha}^{-1} \mathrm{a}^{-1}$ on derogation farms.

Several authors have discussed the link between land use practices, hydrological conditions and $\mathrm{N}$ availability (Andrade and Stigter, 2009; Badruzzaman et al., 2012; Kaçaroglu, 1999). Although nitrate is often not the major form of $\mathrm{N}$ application to agricultural land, it is usually the major form observed in recharge (Böhlke, 2002). In addition, in agriculture-dominated areas not only the total amount of $\mathrm{N}$ application is relevant. Also different agronomic practices of $\mathrm{N}$ application have a consequence on the likelihood and amount of $\mathrm{N}$ leaching (Liu et al., 2013; Oenema et al., 2012). For example, the type of $\mathrm{N}$ applied has an influence on the leaching behaviour throughout the year. Inorganic $\mathrm{N}$ fertilisers are on the one hand immediately available for the plant, but on the other hand highly susceptible to leaching, whereas organic $\mathrm{N}$ fertiliser provide a more constant source of nitrate for the plant on a long-term basis due to mineralisation processes (Whitehead, 1995). Best nutrient management practices are contributing to an increased $\mathrm{N}$ use efficiency which directly implies reduced nitrate loss from surface to groundwater (Rahman et al., 2011; Buckley and Carney, 2013; Oenema et al., 2005). Huebsch et al. (2013) used multiple linear regression to explore the impact of agronomic practices on nitrate concentrations in karst groundwater on a similar site and concluded that improvements in management, such as timing of slurry application, reductions in inorganic fertiliser usage or the change from ploughing to minimum cultivation reseeding, contributed to reduced nitrate concentrations in groundwater.

In addition to mobilisation and dilution processes, seasonal variations need to be addressed. Mineralisation of organic $\mathrm{N}$ can also lead to a different leaching behaviour throughout the year. For example, Mudarra et al. (2012) linked increased mobilisation of nitrate at the Sierra del ReyLos Tajos carbonate aquifer in autumn with increased soil microbial activities, which are directly related to decreased evaporation and increased soil moisture. In contrast, Panno and Kelly (2004) recorded a seasonal trend with greatest ni- 
trate concentrations during late spring and summer and lowest during late fall and winter. Interestingly, Arheimer and Lidén (2000) monitored riverine inorganic and organic $\mathrm{N}$ concentrations from agricultural catchments and showed that inorganic $\mathrm{N}$ concentrations were lower during summer and higher during autumn, whereas organic $\mathrm{N}$ was higher in summer than during the rest of the year.

Similarly, Bende-Michel et al. (2013) linked riverine nitrate response with agricultural source availability throughout the year (e.g. time of inorganic and organic $\mathrm{N}$ fertilisation; nitrate build-up from organic matter in summer after organic $\mathrm{N}$ fertiliser application) and with hydrologic mobilisation due to a change from low to high flow conditions. They assumed that higher peaks of nutrient concentration response should occur (1) during spring after inorganic fertiliser application, (2) during autumn because of increased mineralisation and nitrification processes of organic matter in summer and eventually (3) during winter due to possible expansion of the source area during high flow conditions. In addition, Rowden (2001) showed that larger losses of applied N occurred during wetter years (concentrations and loads). Rainfall intensity and duration is influencing soil moisture. Wet conditions coupled with high nitrate availability in soil due to accumulation intensify leaching from the soil and in the unsaturated zone (Di and Cameron, 2002; Stark and Richards, 2008). In the present study site, the highest peaks of mobilised nitrate concentrations occurred in November 2011 and between June and September of 2012. Seasonal variations are driven by recharge and $\mathrm{N}$ availability at the surface. During the summer period, on the one hand, intensive recharge may transport lower nitrate concentrations if there is a lot of plant growth but on the other hand, it also may increase transport if there is inorganic $\mathrm{N}$ in the soil after fertilisation application. During autumn reduced crop uptake and increased recharge due to longer and more intensified rainfall events typically increases leaching of residual $\mathrm{N}$ in soil (Patil et al., 2010).

Because of rapidly changing concentrations of nitrate and other chemical or microbial contaminants in karst systems, traditional sampling strategies with sampling intervals of weeks to months are inadequate to assess water quality in such systems. This is especially of interest in context of the EU Water Framework Directive, which requires improving the quality of critical water bodies affected by high nitrate from groundwater, such as estuaries and coastal waters. In addition, high-resolution monitoring offers the possibility to detect predominance of mobilisation that can lead to sudden nitrate peaks above the MAC. Hence, if karst groundwater is used as drinking water this technique can help to prevent serious threat to humans and animals such as toxicity in livestock (Di and Cameron, 2002) or methemoglobinemia in infants also known as the "blue baby syndrome" which can progress rapidly to cause coma and death (Knobeloch et al., 2000). An intensification of high-resolution monitoring in the future is therefore essential to assure good water qual- ity of karst groundwater and water bodies highly affected by karst groundwater.

\section{Conclusions}

The proposed conceptual model of nitrate response in karst systems is able to explain various nitrate response scenarios, the nitrate patterns at the spring of the current study and the findings from other studies. In the current study, four possible nitrate response scenarios in karst aquifers to storm events were hypothesised. Scenario 1 relates to mobilised nitrate concentrations, Scenario 2 diluted nitrate concentrations, Scenario 3 a combination of mobilised and diluted nitrate concentrations during one event and Scenario 4 mobilised and diluted nitrate concentrations during multiple events. The proposed conceptual model of nitrate in karst systems elucidates the relation of nitrate responses at karst springs with driving factors such as hydrological conditions, $\mathrm{N}$ availability through land use and karst features. Predominance of mobilisation or dilution and therefore rapid rise or decline of nitrate concentrations during storm events depend highly on the availability of nitrate accumulated in soil and unsaturated zone. A well-developed karst system as well as wet conditions are crucial for rapid transport and have an influence on the intensity and time lag of nitrate concentration changes. Differences regarding predominance of dilution or mobilisation processes during different storm events on the same study site occur if (1) the source of $\mathrm{N}$ at the surface changes over time and/or (2) the activation of different flow paths causes mixing of water sources containing more or less nitrate than the average nitrate concentration in groundwater at the study site. The presented conceptual model of nitrate responses in karst systems contributes to a more comprehensive understanding of nitrate occurrences in the environment and therefore also facilitates an improved implementation of the EU Water Framework Directive in environmental activities, planning and policy. Finally, the study has also highlighted the important role of continuous and long-term nitrate monitoring in karst systems.

Acknowledgements. The authors would like to acknowledge the Teagasc Walsh Fellowship scheme for funding this study. Furthermore, we gratefully acknowledge Tristan G. Ibrahim from Teagasc, the farm staff at Dairygold Farm for supporting the field work and in particular the farm manager Steven Fitzgerald as well as the staff of Johnstown Castle water laboratories for analysing the groundwater samples. In addition, we would like to thank the Irish Meteorological Service Met Èreann for providing meteorological data.

The service charges for this open access publication have been covered by a Research Centre of the Helmholtz Association.

Edited by: A. D. Reeves 


\section{References}

Andrade, A. I. A. S. S. and Stigter, T. Y.: Multi-method assessment of nitrate and pesticide contamination in shallow alluvial groundwater as a function of hydrogeological setting and land use, Agr. Water Manage., 96, 1751-1765, doi:10.1016/j.agwat.2009.07.014, 2009.

Arheimer, B., and Lidén, R.: Nitrogen and phosphorus concentrations from agricultural catchments - influence of spatial and temporal variables, J. Hydrol., 227, 140-159, doi:10.1016/S00221694(99)00177-8, 2000.

Atkinson, T.: Diffuse flow and conduit flow in limestone terrain in the Mendip Hills, Somerset (Great Britain), J. Hydrol., 35, 93110, 1977.

Badruzzaman, M., Pinzon, J., Oppenheimer, J., and Jacangelo, J. G.: Sources of nutrients impacting surface waters in florida: A review, J. Environ. Manage., 109, 80-92, 2012.

Baedke, S. and Krothe, N.: Derivation of effective hydraulic parameters of a karst aquifer from discharge hydrograph analysis, Water Resour. Res., 37, 13-19, 2001.

Bakalowicz, M.: Karst groundwater: A challenge for new resources, Hydrogeol. J., 13, 148-160, doi:10.1007/s10040-004-0402-9, 2005.

Bakalowicz, M. and Mangion, J.: The limestone aquifers of malta: Their recharge conditions from isotope and chemical surveys, IAHS-AISH Publication, 49-54, 2003.

Baran, N., Lepiller, M., and Mouvet, C.: Agricultural diffuse pollution in a chalk aquifer (trois fontaines, france): Influence of pesticide properties and hydrodynamic constraints, J. Hydrol., 358, 56-69, doi:10.1016/j.jhydrol.2008.05.031, 2008.

Bende-Michl, U., Verburg, K., and Cresswell, H.: High-frequency nutrient monitoring to infer seasonal patterns in catchment source availability, mobilisation and delivery, Environ. Monit. Assess., 185, 9191-9219, doi:10.1007/s10661-013-32468, 2013.

Birk, S., Liedl, R., and Sauter, M.: Karst spring responses examined by process-based modeling, Ground Water, 44, 832-836, doi:10.1111/j.1745-6584.2006.00175.x, 2006.

Böhlke, J.-K.: Groundwater recharge and agricultural contamination, Hydrogeol. J., 10, 153-179, doi:10.1007/s10040-001-01833, 2002.

Buckley, C. and Carney, P.: The potential to reduce the risk of diffuse pollution from agriculture while improving economic performance at farm level, Environ. Sci. Pol., 25, 118-126, 2013.

Butscher, C., Auckenthaler, A., Scheidler, S., and Huggenberger, P.: Validation of a numerical indicator of microbial contamination for karst springs, Ground Water, 49, 66-76, 2011.

Campbell, J. L., Hornbeck, J. W., Mitchell, M. J., Adams, M. B., Castro, M. S., Driscoll, C. T., Kahl, J. S., Kochenderfer, J. N., Likens, G. E., and Lynch, J. A.: Input-output budgets of inorganic nitrogen for 24 forest watersheds in the northeastern United States: a review, Water, Air, and Soil Pollution, 151, 373-396, 2004.

Di, H. J. and Cameron, K. C.: Nitrate leaching in temperate agroecosystems: Sources, factors and mitigating strategies, Nutr. Cycl. Agroecosys., 64, 237-256, doi:10.1023/a:1021471531188, 2002.
Di, H. J., Cameron, K. C., Moore, S., and Smith, N. P.: Nitrate leaching and pasture yields following the application of dairy shed effluent or ammonium fertilizer under spray or flood irrigation: results of a lysimeter study, Soil Use Manage., 14, 209-214, 1998.

Drolc, A. and Vrtovšek, J.: Nitrate and nitrite nitrogen determination in waste water using on-line uv spectrometric method, Bioresource Technol., 101, 4228-4233, doi:10.1016/j.biortech.2010.01.015, 2010.

European Community (EC): Council Directive 91/676/EEC of 21 May 1991 concerning the protection of waters against pollution by nitrates from agricultural sources, Off. J. Eur. Commun., 1-8, 1991.

Einsiedl, F. and Mayer, B.: Hydrodynamic and microbial processes controlling nitrate in a fissured-porous karst aquifer of the Franconian Alb, Southern Germany, Environ. Sci. Technol., 40, 6697-6702, 2006.

Einsiedl, F., Maloszewski, P., and Stichler, W.: Estimation of denitrification potential in a karst aquifer using the ${ }_{15} \mathrm{~N}$ and ${ }_{18} \mathrm{O}$ isotopes of $\mathrm{NO}_{3}^{-}$, Biogeochemistry, 72, 67-86, 2005.

Ford, D. C. and Williams, P. W.: Karst hydrogeology and geomorphology, John Wiley \& Sons, 2007.

Gächter, R., Steingruber, S., Reinhardt, M., and Wehrli, B.: Nutrient transfer from soil to surface waters: Differences between nitrate and phosphate, Aquat. Sci., 66, 117-122, doi:10.1007/s00027003-0661-x, 2004.

Galloway, J. N. and Cowling, E. B.: Reactive nitrogen and the world: 200 years of change, Ambio, 31, 64-71, 2002.

Geological Survey of Ireland (GSI): The Karst of Ireland - Limestone Landscapes, Caves and Groundwater Drainage Systems, 1-37, 2000.

Goldscheider, N., Pronk, M., and Zopfi, J.: New insights into the transport of sediments and microorganisms in karst groundwater by continuous monitoring of particle-size distribution, Geologia Croatica, 63, 137-142, 2010.

Grimmeisen, F., Zeemann, M., Sawarieh, A., Wolf, L. and Goldscheider, N.: Groundwater protection of an urbanized karst area with semi-arid climate - Case study Hazzir spring, Wadi Shueib, Jordan, Poster, Grundwasserschutz und Grundwassernutzung FH-DGG-Tagung, Dresden, 2012 (in German).

Hem, J. D.: Study and interpretation of the chemical characteristics of natural water, US Geological Survey, Water Supply Paper 2254, 1-263, 1985.

Heffernan, J. B., Albertin, A. R., Fork, M. L., Katz, B. G., and Cohen, M. J.: Denitrification and inference of nitrogen sources in the karstic Floridan Aquifer, Biogeosciences, 9, 1671-1690, doi:10.5194/bg-9-1671-2012, 2012.

Huebsch, M., Horan, B., Blum, P., Richards, K. G., Grant, J., and Fenton, O.: Impact of agronomic practices of an intensive dairy farm on nitrogen concentrations in a karst aquifer in Ireland, Agric. Ecosyst. Environ., 179, 187-199, doi:10.1016/j.agee.2013.08.021, 2013.

Jahangir, M. M. R., Johnston, P., Khalil, M. I., Hennessy, D., Humphreys, J., Fenton, O., and Richards, K. G.: Groundwater: A pathway for terrestrial $\mathrm{c}$ and $\mathrm{n}$ losses and indirect greenhouse gas emissions, Agriculture, Ecosystems and Environment, 159, 40-48, 2012a. 
Jahangir, M. M. R., Johnston, P., Khalil, M. I., and Richards, K. G.: Linking hydrogeochemistry to nitrate abundance in groundwater in agricultural settings in ireland, J. Hydrol., 448-449, 212-222, doi:10.1016/j.jhydrol.2012.04.054, 2012b.

Kaçaroglu, F.: Review of groundwater pollution and protection in karst areas, Water, Air, and Soil Pollution, 113, 337-356, 1999.

Kamphake, L. J., Hannah, S. A., and Cohen, J. M.: Automated analysis for nitrate by hydrazine reduction, Water Res., 1, 205-216, 1967.

Kiraly, L.: Modelling karst aquifers by the combined discrete channel and continuum approach, Bulletin d'Hydrogéologie, 16, 7798, 1998.

Knobeloch, L., Salna, B., Hogan, A., Postle, J., and Anderson, H.: Blue babies and nitrate-contaminated well water, Environ. Health Persp., 108, 675-678, doi:10.2307/3434890, 2000.

Kurz, I., Coxon, C., Tunney, H., and Ryan, D.: Effects of grassland management practices and environmental conditions on nutrient concentrations in overland flow, J. Hydrol., 304, 35-50, 2005.

L'hirondel, J.: Nitrate and man: Toxic, harmless or beneficial?, CABI, 2002.

Landig, F.: Determination of nitrate fluxes in a fractured karst limestone aquifer below a dairy farm in Co. Cork, Ireland, University of Tübingen, 1-93, 2009.

Landig, F., Fenton, O., Bons, P., Hennessy, D., Richards, K., and Blum, P.: Estimation of nitrate discharge in a fractured limestone aquifer below a dairy farm in Ireland, IAHS-AISH Publication, 469-472, 2011.

Liao, L., Green, C. T., Bekins, B. A., and Böhlke, J. K.: Factors controlling nitrate fluxes in groundwater in agricultural areas, Water Resour. Res., 48, W00L09, doi:10.1029/2011wr011008, 2012.

Liu, R., Zhang, P., Wang, X., Chen, Y., and Shen, Z.: Assessment of effects of best management practices on agricultural nonpoint source pollution in xiangxi river watershed, Agricult. Water Manage., 117, 9-18, doi:10.1016/j.agwat.2012.10.018, 2013.

Mahler, B. J., Valdes, D., Musgrove, M., and Massei, N.: Nutrient dynamics as indicators of karst processes: Comparison of the chalk aquifer (normandy, france) and the edwards aquifer (Texas, USA), J. Contam. Hydrol., 98, 36-49, doi:10.1016/j.jconhyd.2008.02.006, 2008.

Mellander, P. E., Jordan, P., Melland, A. R., Murphy, P. N. C., Wall, D. P., Mechan, S., Meehan, R., Kelly, C., Shine, O., and Shortle, G.: Quantification of phosphorus transport from a karstic agricultural watershed to emerging spring water, Environ. Sci. Technol., 47, 6111-6119, 2013.

Mudarra, M., Andreo, B., and Mudry, J.: Monitoring groundwater in the discharge area of a complex karst aquifer to assess the role of the saturated and unsaturated zones, Environ. Earth Sci., 65, 2321-2336, doi:10.1007/s12665-011-1032-x, 2012.

Musgrove, M., Katz, B. G., Fahlquist, L. S., Crandall, C. A., and Lindgren, R. J.: Factors Affecting Public-Supply Well Vulnerability in Two Karst Aquifers, Groundwater, 52, 63-75, doi:10.1111/gwat.12201, 2014.

Oenema, O., Van Liere, L., and Schoumans, O.: Effects of lowering nitrogen and phosphorus surpluses in agriculture on the quality of groundwater and surface water in the netherlands, J. Hydrol., 304, 289-301, 2005.

Oenema, J., van Ittersum, M., and van Keulen, H.: Improving nitrogen management on grassland on commercial pilot dairy farms in the Netherlands, Agriculture, Ecosystems and Environment, 162, 116-126, 2012.

Official Journal of the European 871 Communities (OJEC): Directive 2000/60/EC of the European Parliament and of the council of 23rd October 2000 establishing a framework for Community action in the field of water policy, 1-72, 2000.

Panno, S.: Groundwater contamination in karst terrain of southwestern Illinois, Environmental geology (USA), 1996.

Panno, S. V. and Kelly, W. R.: Nitrate and herbicide loading in two groundwater basins of illinois' sinkhole plain, J. Hydrol., 290, 229-242, doi:10.1016/j.jhydrol.2003.12.017, 2004.

Panno, S., Hackley, K., Hwang, H., and Kelly, W.: Determination of the sources of nitrate contamination in karst springs using isotopic and chemical indicators, Chem. Geol., 179, 113-128, 2001.

Patil, R. H., Laegdsmand, M., Olesen, J. E., and Porter, J. R.: Effect of soil warming and rainfall patterns on soil $\mathrm{N}$ cycling in Northern Europe, Agriculture, Ecosystems and Environment, 139, 195-205, 2010.

Peterson, E. W., Davis, R. K., Brahana, J. V., and Orndorff, H. A.: Movement of nitrate through regolith covered karst terrane, northwest arkansas, J. Hydrol., 256, 35-47, doi:10.1016/S00221694(01)00525-X, 2002.

Plagnes, V. and Bakalowicz, M.: The protection of a karst water resource from the example of the larzac karst plateau (south of france): A matter of regulations or a matter of process knowledge?, Eng. Geol., 65, 107-116, doi:10.1016/S00137952(01)00117-X, 2002.

Pronk, M., Goldscheider, N., and Zopfi, J.: Particle-size distribution as indicator for fecal bacteria contamination of drinking water from karst springs, Environ. Sci. Technol., 41, 8400-8405, 2007.

Pronk, M., Goldscheider, N., and Zopfi, J.: Microbial communities in karst groundwater and their potential use for biomonitoring, Hydrogeol. J., 17, 37-48, 2009.

Pu, J., Yuan, D., He, Q., Wang, Z., Hu, Z., and Gou, P.: Highresolution monitoring of nitrate variations in a typical subterranean karst stream, chongqing, china, Environ. Earth Sci., 64, 1985-1993, doi:10.1007/s12665-011-1019-7, 2011.

Rahman, R., Frind, E. O., and Rudolph, D. L.: Assessing the impact of beneficial management practices for controlling nitrate concentrations in well water, IAHS-AISH publication, 326-329, 2011.

Ribolzi, O., Andrieux, P., Valles, V., Bouzigues, R., Bariac, T., and Voltz, M.: Contribution of groundwater and overland flows to storm flow generation in a cultivated mediterranean catchment. Quantification by natural chemical tracing, J. Hydrol., 233, 241257, doi:10.1016/S0022-1694(00)00238-9, 2000.

Rowden, R., Liu, H., and Libra, R.: Results from the big spring basin water quality monitoring and demonstration projects, iowa, USA, Hydrogeol. J., 9, 487-497, doi:10.1007/s100400100150, 2001.

Ryan, M. and Meiman, J.: An examination of short-term variations in water quality at a karst spring in kentucky, Ground Water, 34, 23-30, doi:10.1111/j.1745-6584.1996.tb01861.x, 1996.

Schulte, R. P. O., Diamond, J., Finkele, K., Holden, N. M., and Brereton, A. J.: Predicting the soil moisture conditions of irish grasslands, Irish J. Agricult. Food Res., 44, 95-110, 2005.

Schwientek, M., Osenbrück, K., and Fleischer, M.: Investigating hydrological drivers of nitrate export dynamics in two agricultural catchments in germany using high-frequency data series, Env- 
iron. Earth Sci., 69, 381-393, doi:10.1007/s12665-013-2322-2, 2013.

Sebestyen, S. D., Boyer, E. W., Shanley, J. B., Kendall, C., Doctor, D. H., Aiken, G. R., and Ohte, N.: Sources, transformations, and hydrological processes that control stream nitrate and dissolved organic matter concentrations during snowmelt in an upland forest, Water Resour. Res., 44, W12410, doi:10.1029/2008wr006983, 2008.

Shuster, E. T. and White, W. B.: Seasonal fluctuations in the chemistry of lime-stone springs: A possible means for characterizing carbonate aquifers, J. Hydrol., 14, 93-128, doi:10.1016/00221694(71)90001-1, 1971.

Sophocleous, M.: On understanding and predicting groundwater response time, Ground Water, 50, 528-540, doi:10.1111/j.17456584.2011.00876.x, 2012.

Spalding, R. F. and Exner, M. E.: Occurrence of nitrate in groundwater - a review, J. Environ. Qual., 22, 392-402, 1993.

Stark, C. H. and Richards, K. G.: The continuing challenge of agricultural nitrogen loss to the environment in the context of global change and advancing research, Dyn. Soil Dyn. Plant, 2, 1-12, 2008.

Stigter, T. Y., Carvalho Dill, A. M. M., and Ribeiro, L.: Major issues regarding the efficiency of monitoring programs for nitrate contaminated groundwater, Environ. Sci. Technol., 45, 8674-8682, doi:10.1021/es201798g, 2011.

Storey, M. V., van der Gaag, B., and Burns, B. P.: Advances in online drinking water quality monitoring and early warning systems, Water Res., 45, 741-747, 2011.

Stueber, A. M. and Criss, R. E.: Origin and transport of dissolved chemicals in a karst watershed, southwestern illinois, J. Am. Water Resour. Assoc., 41, 267-290, doi:10.1111/j.17521688.2005.tb03734.x, 2005.
Tedd, K. M., Coxon, C. E., Misstear, B. D. R., Daly, D., Craig, M., Mannix, A., and Hunter Williams, N. H.: An integrated pressure and pathway approach to the spatial analysis of groundwater nitrate: A case study from the southeast of ireland, Sci. Tot. Environ., 476-477, 460-476, doi:10.1016/j.scitotenv.2013.12.085, 2014.

Toran, L. and White, W. B.: Variation in nitrate and calcium as indicators of recharge pathways in nolte spring, pa, Environ. Geol., 48, 854-860, doi:10.1007/s00254-005-0018-y, 2005.

Walkowiak, D. K.: Isco Open Channel Flow Measurement Handbook, Teledyne Isco Inc., Lincoln, 1-520, 2006.

White, W. B.: Geomorphology and hydrology of karst terrains, Oxford university press New York, 1988.

Whitehead, D. C.: Grassland Nitrogen, CAB International, Wallingford, Oxon, UK, 1-416, 1995.

Worthington, S. R., Ford, D. C., and Beddows, P. A.: Porosity and permeability enhancement in unconfined carbonate aquifers as a result of dissolution, Speleogenesis Evolution of Karst Aquifers: Huntsville, Alabama, National Speleological Society, Inc, 463472, 2000.

Yang, P., Yuan, D., Ye, X., Xie, S., Chen, X., and Liu, Z.: Sources and migration path of chemical compositions in a karst groundwater system during rainfall events, Chin. Sci. Bull., 58, 24882496, doi:10.1007/s11434-013-5762-x, 2013.

Zhijun, W., Pingheng, Y., Qiufang, H., Daoxian, Y., Wenhao, Y., and Yinglun, K.: Hydrochemical variation and its influencing factors in typical karst subterranean river in sw china, 4th International Conference on Bioinformatics and Biomedical Engineering (iCBBE), 1-5, doi:10.1109/icbbe.2010.5518244, 2010. 